九州大学学術情報リポジトリ

Kyushu University Institutional Repository

\title{
Changes in Qualitative Components of two Melon Cultivars during Maturation
}

Quadir, Mohammed Abdul

Institute of Postgraduate Studies in Agriculture

Shiraishi, Shinichi

University Farm, Faculty of Agriculture, Kyushu University

Ali, Mohammad

Laboratory of Horticultural Science, Faculty of Agriculture, Kyushu University

https://doi.org/10.5109/23949

出版情報: 九州大学大学院農学研究院紀要. 35 (1/2)，pp.51-57，1990-12. Kyushu University バージョン：

権利関係 : 


\title{
Changes in Qualitative Components of two Melon Cultivars during Maturation
}

\author{
Mohammed Abdul Quadir*, Shin-ichi Shiraishi** \\ and Mohammad Ali \\ Laboratory of Horticultural Science, Faculty of \\ Agriculture, Kyushu University 46-10, Fukuoka 812, Japan.
}

(Received June 26, 1990)

\begin{abstract}
Fruit quality of two netted melon (Cucumis melo L. reticulatus group) cultivars, -Green Wave and Natsukei 6 gou were examined at 35, 40, 45, and 50 days after pollination (DAP) as well as fruit stored for 5 days after the harvest of 50 DAP. It was observed that fruit size, weight, brix and sugar content increased with the maturity but had no significant increase due to storing. For acid content, there was in general a declining pattern with the maturity but significant reduction at the final stage of maturity was observed. The total amino acid including monoamino carboxylic and sweet and sour amino acids increased significantly with the advancement of maturity but found to be decreased at storing. Difference for almost all the qualitative components were observed for two cultivars. In general, fruit of the cv. Green wave were sweeter and of more juicy nature because of higher sucrose and amino acid contents than that of the cv. Natsukei 6 gou.
\end{abstract}

\section{INTRODUCTION}

Wide variations of melon (Cucumis melo L.) cultivars exist in respect of fruit characteristics including qualitative aspects. The most popular group among the melon is designated as netted melons (C. melo L. reticulatus group). A number of netted melon cultivars have been developed with variable fruit quality. It has been observed that the sugar accumulation as well as acid content contribute the commercial quality of melon fruit. In addition amino acid also makes important contribution to the taste quality. There are quite a few reports on the accumulation of sugar in melon fruit (Eguchi and Fujieda, 1970 ; Mizuno et al., 1971 and Yoshida et al., 1989) but reports on the changes of amino acids and other organic acids are meagre. The present study, therefore, examines the change of acid, sugar and amino acid content in relation to the maturity of fruit aiming at determining the proper harvesting stage.

\section{MATERIALS AND METHODS}

Seeds of netted melon (C. melo L. reticulatus group) cvs. Green Wave and Natsukei 6 gou were sown on sand on May 8, 1989 and at cotyledonary leaf stage seedlings were transferred into plastic pots. At two true leaves expanding stage seedlings were transplanted into the sandy soil bed under plastic film greenhouse

\footnotetext{
* Institute of Postgraduate Studies in Agriculture, Salna, Gazipur, Bangladesh.

** University Farm, Faculty of Agriculture, Kyushu University, Kasuyamachi, Fukuoka 811-23
} 
maintaining $35 \pm 3{ }^{\circ} \mathrm{C}$ to $25 \pm 3^{\circ} \mathrm{C}$ during day and night, respectively. Single-stem training method was followed for all the plants. Perfect flowers on lateral branches of 11 to 15 th node were pollinated and as the fruit started developing, the top of the branch was pinched after 22nd node. Only one fruit was finally kept per plant. Fruit were harvested for qualitative analysis at 35, 40, 45 and 50 days after pollination (DAP). Another treatment consisted of fruits stored for 5 days after the last harvest of 50 DAP. For every harvesting stage fruit size, weight and brix of fruit juice were recorded.

For chemical analysis, $100 \mathrm{~g}$ of flesh tissue were ground with quartz sand and after maceration the samples were centrifuged to $10,000 \mathrm{rpm}$ for 15 minutes at $0^{\circ} \mathrm{C}$. The final volume was then made upto $500 \mathrm{ml}$. However, the calculations were corrected on the basis of $100 \mathrm{~g}$.

Sugar content was measured by the Bertrand method. Total acidity was determined by titration against $0.1 \mathrm{~N} \mathrm{NaOH}$ after passing the extract through a cationexchange colum (Amberlite CG-120) and acidity was expressed as \% citric acid $(\mathrm{g} / 100 \mathrm{~g})$. Free acidity was determined by titration against $0.1 \mathrm{~N} \mathrm{NaOH}$ and was also expressed as $\%$ citric acid.

Preparation and determination of amino acid content were performed by the ion exchange column chromatography.

\section{RESULTS AND DISCUSSION}

Fruit characteristics :

For both the cultivars fruit weight and size increased progressively with the advancement of maturity (Table 1). However, the fruit growth was rapid upto 45 DAP in cv. Green Wave and in cv. Natsukei 6 gou the growth continued upto 50th days. The rind appeared to be reducing at maturation. Initially cv. Green Wave had thick rind (at $35 \& 40$ DAP) but was found to be thinned at ripening. In case of cv. Natsukei 6 gou the medium size rind gradually became slim and finally rind size appeared to be slightly thicker than that of cv. Green Wave. Both cultivars had attractive greenish ash color at final maturity. Flesh color was greenish white for

Table 1. Fruit characteristics of two cultivars of melon at various stages of maturity.

\begin{tabular}{|c|c|c|c|c|c|}
\hline Cultivars & $\begin{array}{l}\text { Days after } \\
\text { pollination }\end{array}$ & $\begin{array}{l}\text { Length } \\
\text { (cm) }\end{array}$ & $\begin{array}{c}\text { Maximum } \\
\text { diameter } \\
(\mathrm{cm})\end{array}$ & $\begin{array}{l}\text { Rind } \\
\text { thickness } \\
(\mathrm{cm})\end{array}$ & $\begin{array}{c}\text { Weight } \\
\text { (g) }\end{array}$ \\
\hline \multirow[t]{5}{*}{ Green Wave } & 35 & 15.7 & 13.4 & 110 & 1628 \\
\hline & 40 & 16.3 & 13.9 & 0.81 & 1748 \\
\hline & 45 & 17.2 & 14.4 & 0.52 & 1843 \\
\hline & 50 & 17.5 & 14.7 & 0.43 & 1862 \\
\hline & $50+5$ days storing & 17.5 & 14.7 & 0.38 & 1862 \\
\hline \multirow[t]{5}{*}{ Natsukei 6 gou } & 35 & 12.1 & 13.2 & 0.71 & 1282 \\
\hline & 40 & 13.0 & 13.8 & 0.50 & 1445 \\
\hline & 45 & 13.5 & 14.3 & 0.45 & 1605 \\
\hline & 50 & 14.0 & 14.6 & 0.45 & 1671 \\
\hline & $50+5$ days storing & 14.0 & 14.5 & 0.43 & 1669 \\
\hline
\end{tabular}


both the cultivars. The crispiness decreased with the maturity and particularly for cv. Green Wave, when the fruit were harvested at 45 DAP the flesh was found to be quite soft whereas similar stage was observed in cv. Natsukei 6 gou at 50 DAP. For both cultivars fruit stored for 5 days after harvesting at 50 DAP became soft and juicy with cv. Green Wave having more juicy nature. Mizuno et al. (1971) reported increased fruit size and weight with the maturity.

\section{Brix :}

Brix percent found to be advanced with the maturity of fruit. For both cultivars there was dramatic shift of brix percent from 35 to 40 days and then advanced gradually upto 50 DAP. No significant increase in this respect was observed after 5 days of storing. The cv. Green Wave had the higher brix for the corresponding harvesting stages than those of $\mathrm{cv}$ : Natsukei 6 gou. The cv. Green Wave reached $17.8 \%$ brix as compared to $13.7 \%$ of cv. Natsukei 6 gou. Mizuno et al.(1971) and Yoshida et al. (1989) also reported brix of 15.0 or more for different cultivars of netted melons.

\section{Total and reducing sugar :}

The total sugar content also showed similar pattern of increase as the brix. Whereas the reducing sugar seemed to be decreased with the maturity (Table 2). However, total sugar content was comparatively higher for cv. Green Wave than cv. Natsukei 6 gou. The reducing sugar content did not differ between the cultivars. Regarding the sugar content there was two significant shift of sucrose accumulation in cv. Green Wave - one from 35 to 40 days and the other from 45 to 50 DAP. Whereas for cv. Natsukei 6 gou the progression in accumulation of sucrose was higher from 35 to 40 days and then there was steady accumulation. Fruit of $\mathrm{cv}$. Green Wave accumulated $12.5 \%$ sucrose as compared to $8.6 \%$ of cv. Natsukei 6 gou at the end of observation. Mizuno etal. (1971) also reported similar increasing tendency of sugar accumulation in melon and recorded $10.4 \%$ sucrose for fruit after 50 days of flower-

Table 2. Brix, total sugar, reducing sugar and sucrose content of two cultivars of melon at various stages of maturity.

\begin{tabular}{llcccc}
\hline \multirow{2}{*}{$\begin{array}{l}\text { Cultivars } \\
\text { DAP }\end{array}$} & Brix & $\begin{array}{c}\text { Total } \\
\text { sugar } \\
\text { Green }\end{array}$ & $(\%)$ & $\begin{array}{c}\text { Reducing } \\
\text { sugar } \\
(\mathrm{g} .)^{*}\end{array}$ & $\begin{array}{c}\text { Sucrose } \\
(\mathrm{g} .)^{*}\end{array}$ \\
& 35 & & & & \\
& 40 & 12.2 & 10.43 & 6.73 & 3.70 \\
& 45 & 15.4 & 11.76 & 3.76 & 8.00 \\
Natsukei 6 gou & 50 & 16.6 & 12.27 & 3.18 & 9.09 \\
& $50+5$ days storing & 17.5 & 15.07 & 3.04 & 12.03 \\
& 35 & 17.8 & 15.50 & 2.97 & 12.53 \\
& 40 & 9.7 & 8.27 & 5.73 & 2.54 \\
& 45 & 11.6 & 10.13 & 4.00 & 6.13 \\
& 50 & 12.6 & 10.35 & 3.89 & 6.46 \\
& $50+5$ days storing & 13.7 & 10.89 & 3.74 & 7.15 \\
\end{tabular}

*Per $100 \mathrm{~g}$ basis ; DAP-days after pollination 
Table 3. Acid contents of two cultivars of melon during maturation

\begin{tabular}{llcc}
\hline Cultivars & DAP & $\begin{array}{c}\text { Total } \\
\text { acidity } \\
(\mathrm{g})^{*}\end{array}$ & $\begin{array}{c}\text { Free } \\
\text { acidity } \\
(\mathrm{g})^{*}\end{array}$ \\
& 35 & 0.829 & 0.179 \\
Green Wave & 40 & 0.605 & 0.084 \\
& 45 & 0.532 & 0.077 \\
Natsukei 6 gou & 50 & 0.525 & 0.058 \\
& $50+5$ days storing & 0.275 & 0.048 \\
& 40 & 0.564 & 0.118 \\
& 45 & 0.544 & 0.090 \\
& 50 & 0.544 & 0.067 \\
& $50+5$ days storing & 0.535 & 0.058 \\
& 0.352 & 0.045 \\
\hline
\end{tabular}

*Per $100 \mathrm{~g}$ basis; DAP-days after pollination

ing.

\section{Total and free acid :}

Both the total and free acid seemed to be decreased with the maturity. However, there was sharp decline in this regard for fruit stored for 5 days after harvesting at 50 DAP (Table 3). Similar phenomenon was recorded for both cultivars. The decrease of total acid for cv. Green Wave was sharp at the begining of maturity (35 to 45 DAP) and then was rather steady upto 50 days, and after 5 days storing it declined sharply. For cv. Natsukei 6 gou, the decrease was rather slow until 50 DAP and then similar to that of cv. Green Wave it dropped quickly at storing. Both the cultivars had almost similar pattern of decrease in free acid content with cv. Green Wave having higher initial content. The decrease of acid contents with maturity is common phenomenon in many fleshy fruits.

\section{Amino acid content :}

Table 4 presents the contents of individual amino acid, total amino acid and groups of amino acids on the basis of chemical construction and organoleptic assessment.

In terms of total amino acid content, both the cultivars showed increasing pattern upto the final stage of harvent (50 DAP) and then after 5 days of storing the amount decreased. At 50 DAP total content of amino acid was found to be almost similar for cv. Green Wave and cv. Natsukei 6 gou with 7858 and $7691 \mu \mathrm{M} / 100 \mathrm{~g}$, respectively. However, for cv. Green Wave the total content started to rise after 40 days. Whereas for cv. Natsukei 6 gou it started from the initial stage of harvest (35 DAP). In general, cv. Green Wave had little higher contents of amino acids as compared to corresponding harvesting stages of cv. Natsukei 6 gou.

The most abundant amino acids observed in both cultivars were threonine, alanine and glutamic acid which constituted $70 \%$ of the total amino acid contents. Besides these major amino acids, serine, glycine, aspartic acid, lysine and valine also constituted $20 \%$ of the total content of free amino acids. Cystine was found only at the later 
Table 4. Free amino acid contents $(\mu \mathrm{M} / 100 \mathrm{~g}$ fresh tissue) of two melon cultivars during maturation

\begin{tabular}{|c|c|c|c|c|c|c|c|c|c|c|}
\hline \multirow{2}{*}{ Free amino acids } & \multicolumn{5}{|c|}{$\begin{array}{l}\text { Green Wave } \\
\text { (DAP)* }\end{array}$} & \multicolumn{5}{|c|}{$\begin{array}{l}\text { Natsukei } 6 \text { gou } \\
(D A P)^{*}\end{array}$} \\
\hline & 35 & 40 & 45 & 50 & $\begin{array}{l}50+5 \text { days } \\
\text { storing }\end{array}$ & 35 & 40 & 45 & 50 & $\begin{array}{c}50+5 \text { days } \\
\text { storing }\end{array}$ \\
\hline Aspartic acid & $\begin{array}{r}486.5 \\
(9.1)\end{array}$ & $\begin{array}{c}135.5 \\
(2.4)\end{array}$ & $\begin{array}{l}5.5 \\
(0.1)\end{array}$ & $\begin{array}{r}310.0 \\
(3.8)\end{array}$ & $\begin{array}{l}11.5 \\
(0.2)\end{array}$ & $\begin{array}{r}145.5 \\
(4.1)\end{array}$ & $\begin{array}{l}474.0 \\
(9.7)\end{array}$ & $\begin{array}{r}274.0 \\
(4.5)\end{array}$ & $\begin{array}{r}282.0 \\
(3.8)\end{array}$ & $\begin{array}{c}230.5 \\
(3.7)\end{array}$ \\
\hline Threonine & $\begin{array}{c}189 X .5 \\
(31.9)\end{array}$ & $\begin{array}{l}2529.5 \\
(45.6)\end{array}$ & $\begin{array}{c}2430.0 \\
(38.7)\end{array}$ & $\begin{array}{r}2380.0 \\
(30.3)\end{array}$ & $\begin{array}{l}1643.0 \\
(25.6)\end{array}$ & $\begin{array}{c}1808.5 \\
(52.8)\end{array}$ & $\begin{array}{c}1991.5 \\
(38.8)\end{array}$ & $\begin{array}{r}2286.0 \\
(37.8)\end{array}$ & $\begin{array}{c}2605.5 \\
(34.0)\end{array}$ & $\begin{array}{l}1727.0 \\
(27.7)\end{array}$ \\
\hline Serine & $\begin{array}{l}402.0 \\
(7.6)\end{array}$ & $\begin{array}{l}31.0 \\
(0.6)\end{array}$ & $\begin{array}{l}345.0 \\
(5.5)\end{array}$ & $\begin{array}{r}443.0 \\
(5.6)\end{array}$ & $\begin{array}{l}419.0 \\
(6.5)\end{array}$ & $\begin{array}{c}156.5 \\
(4.6)\end{array}$ & $\begin{array}{r}250.5 \\
(4.8)\end{array}$ & $\begin{array}{l}12.0 \\
(0.3)\end{array}$ & $\begin{array}{r}427.0 \\
(5.6)\end{array}$ & $\begin{array}{r}340.0 \\
(5.5)\end{array}$ \\
\hline Glutamic acid & $\begin{array}{c}626.5 \\
(12.0)\end{array}$ & $\begin{array}{l}759.0 \\
(22.8)\end{array}$ & $\begin{array}{r}1558.0 \\
(24.8)\end{array}$ & $\begin{array}{r}1724.0 \\
(22.0)\end{array}$ & $\begin{array}{l}1429.5 \\
(22.2)\end{array}$ & $\begin{array}{l}271.5 \\
(7.9)\end{array}$ & $\begin{array}{l}679.0 \\
(13.4)\end{array}$ & $\begin{array}{r}1332.0 \\
(22.0)\end{array}$ & $\begin{array}{c}1791.0 \\
(23.1)\end{array}$ & $\begin{array}{r}1044.0 \\
(16.8)\end{array}$ \\
\hline Glycine & $\begin{array}{r}233.0 \\
(4.5)\end{array}$ & $\begin{array}{r}183.0 \\
(3.3)\end{array}$ & $\begin{array}{r}248.0 \\
(4.0)\end{array}$ & $\begin{array}{c}337.0 \\
(4.3)\end{array}$ & $\begin{array}{l}363.0 \\
(5.6)\end{array}$ & $\begin{array}{l}98.0 \\
(2.9)\end{array}$ & $\begin{array}{l}176.5 \\
(3.5)\end{array}$ & $\begin{array}{l}227.0 \\
(3.7)\end{array}$ & $\begin{array}{r}302.5 \\
(4.0)\end{array}$ & $\begin{array}{r}246.5 \\
(4.0)\end{array}$ \\
\hline Alanine & $\begin{array}{l}435.5 \\
(8.0)\end{array}$ & $\begin{array}{l}316.0 \\
(5.71\end{array}$ & $\begin{array}{l}757.5 \\
(12.0)\end{array}$ & $\begin{array}{r}1327.5 \\
(17.0)\end{array}$ & $\begin{array}{l}1401.0 \\
(21.8)\end{array}$ & $\begin{array}{r}124.0 \\
(3.6)\end{array}$ & $\begin{array}{r}471.5 \\
(9.0)\end{array}$ & $\begin{array}{l}576.0 \\
(9.2)\end{array}$ & $\begin{array}{l}965.0 \\
(12.6)\end{array}$ & $\begin{array}{l}1470.5 \\
(23.6)\end{array}$ \\
\hline Cystine & 0.0 & 0.0 & 0.0 & $\begin{array}{r}352.0 \\
(4.5)\end{array}$ & $\begin{array}{r}182.0 \\
(2.8)\end{array}$ & 0.0 & 0.0 & $\begin{array}{l}250.5 \\
(4.8)\end{array}$ & $\begin{array}{r}130.5 \\
(1.6)\end{array}$ & $\begin{array}{l}239.5 \\
(3.8)\end{array}$ \\
\hline Valine & $\begin{array}{l}314.0 \\
(5.9)\end{array}$ & $\begin{array}{r}141.9 \\
(4.5)\end{array}$ & $\begin{array}{c}263.5 \\
(4.2)\end{array}$ & $\begin{array}{r}203.0 \\
(2.6)\end{array}$ & $\begin{array}{r}181.0 \\
(2.8)\end{array}$ & $\begin{array}{r}198.0 \\
(5.8)\end{array}$ & $\begin{array}{r}249.5 \\
(5.0)\end{array}$ & $\begin{array}{r}240.0 \\
(3.9)\end{array}$ & $\begin{array}{l}304.0 \\
(4.0)\end{array}$ & $\begin{array}{c}168.0 \\
(2.7)\end{array}$ \\
\hline Methionine & $\begin{array}{r}203.0 \\
(3.9)\end{array}$ & $\begin{array}{c}149.0 \\
(2.7)\end{array}$ & $\begin{array}{r}148.5 \\
(2.4)\end{array}$ & $\begin{array}{r}137.0 \\
(1.8)\end{array}$ & $\begin{array}{r}108.0 \\
(1.7)\end{array}$ & $\begin{array}{r}129.5 \\
(3.9)\end{array}$ & $\begin{array}{r}132.0 \\
(2.7)\end{array}$ & $\begin{array}{c}173.0 \\
(2.9)\end{array}$ & $\begin{array}{c}197.5 \\
(2.6)\end{array}$ & $\begin{array}{c}75.5 \\
(1.2)\end{array}$ \\
\hline Isoleucine & $\begin{array}{r}143.0 \\
(2.7)\end{array}$ & $\begin{array}{l}76.5 \\
(1.4)\end{array}$ & $\begin{array}{l}52.5 \\
(0.8)\end{array}$ & $\begin{array}{l}52.0 \\
(0.7)\end{array}$ & $\begin{array}{l}53.5 \\
(0.8)\end{array}$ & $\begin{array}{l}64.0 \\
(1.9)\end{array}$ & $\begin{array}{l}66.5 \\
(1.4)\end{array}$ & $\begin{array}{l}77.0 \\
(1.3)\end{array}$ & $\begin{array}{l}81.5 \\
(1.1)\end{array}$ & $\begin{array}{l}64.5 \\
(1.0)\end{array}$ \\
\hline Leucine & $\begin{array}{c}136.5 \\
(2.6)\end{array}$ & $\begin{array}{l}90.5 \\
(1.6)\end{array}$ & $\begin{array}{l}63.0 \\
(1.0)\end{array}$ & $\begin{array}{l}76.0 \\
(1.0)\end{array}$ & $\begin{array}{c}101.5 \\
(1.6)\end{array}$ & $\begin{array}{l}75.5 \\
(2.2)\end{array}$ & $\begin{array}{l}77.0 \\
(1.6)\end{array}$ & $\begin{array}{l}83.5 \\
(1.4)\end{array}$ & $\begin{array}{l}93.0 \\
(1.2)\end{array}$ & $\begin{array}{l}90.5 \\
(1.3)\end{array}$ \\
\hline Tyrosine & $\begin{array}{l}39.5 \\
(0.7)\end{array}$ & $\begin{array}{l}35.0 \\
(0.6)\end{array}$ & $\begin{array}{l}34.5 \\
(0.6)\end{array}$ & $\begin{array}{l}47.5 \\
(0.7)\end{array}$ & $\begin{aligned} 152.0 \\
(2.4)\end{aligned}$ & $\begin{array}{l}28.5 \\
(0.8)\end{array}$ & $\begin{array}{c}27.5 \\
(0.6)\end{array}$ & $\begin{array}{c}44.5 \\
(0.7)\end{array}$ & $\begin{array}{l}38.0 \\
(0.5)\end{array}$ & $\begin{array}{l}36.0 \\
(0.6)\end{array}$ \\
\hline Phenylalanine & $\begin{array}{r}106.0 \\
(2.0)\end{array}$ & $\begin{array}{r}142.0 \\
(2.6)\end{array}$ & $\begin{array}{c}100.0 \\
(1.6)\end{array}$ & $\begin{array}{l}76.0 \\
(1.0)\end{array}$ & $\begin{array}{l}93.5 \\
(1.5)\end{array}$ & $\begin{array}{l}65.0 \\
(1.9)\end{array}$ & $\begin{array}{r}110.5 \\
(2.0)\end{array}$ & $\begin{array}{r}137.0 \\
(2.3)\end{array}$ & $\begin{array}{r}153.0 \\
(2.0)\end{array}$ & $\begin{array}{c}50.0 \\
(0.8)\end{array}$ \\
\hline Histidine & $\begin{array}{l}79.0 \\
(1.4)\end{array}$ & $\begin{array}{l}66.5 \\
(1.2)\end{array}$ & $\begin{array}{l}66.0 \\
(1.1)\end{array}$ & $\begin{array}{l}87.5 \\
(1.1)\end{array}$ & $\begin{array}{c}34.0 \\
(0.5)\end{array}$ & $\begin{array}{l}76.0 \\
(2.2)\end{array}$ & $\begin{array}{c}72.0 \\
(1.5)\end{array}$ & $\begin{array}{l}101.5 \\
(1.7)\end{array}$ & $\begin{array}{l}81.5 \\
(1.1)\end{array}$ & $\begin{array}{l}72.5 \\
(1.2)\end{array}$ \\
\hline Lysine & $\begin{array}{r}216.0 \\
(4.0)\end{array}$ & $\begin{array}{l}129.5 \\
(2.3)\end{array}$ & $\begin{array}{r}118.0 \\
(1.9)\end{array}$ & $\begin{array}{r}182.0 \\
(2.4)\end{array}$ & $\begin{array}{r}119.0 \\
(1.9)\end{array}$ & $\begin{array}{r}120.0 \\
(3.3)\end{array}$ & $\begin{array}{r}204.0 \\
(4.1)\end{array}$ & $\begin{array}{l}156.5 \\
(2.7)\end{array}$ & $\begin{array}{l}90.5 \\
(1.2)\end{array}$ & $\begin{array}{l}260.5 \\
(4.2)\end{array}$ \\
\hline Arginine & $\begin{array}{r}200.0 \\
(3.8) \\
\end{array}$ & $\begin{array}{c}147.5 \\
(2.7) \\
\end{array}$ & $\begin{array}{r}111.0 \\
(1.8) \\
\end{array}$ & $\begin{array}{r}126.0 \\
(1.6)\end{array}$ & $\begin{array}{r}138.5 \\
(2.2) \\
\end{array}$ & $\begin{array}{c}84.5 \\
(2.2) \\
\end{array}$ & $\begin{array}{r}116.0 \\
(2.1)\end{array}$ & $\begin{array}{c}88.5 \\
(1.5) \\
\end{array}$ & $\begin{array}{r}150.0 \\
(1.9)\end{array}$ & $\begin{array}{c}108.5 \\
(1.7) \\
\end{array}$ \\
\hline $\begin{array}{l}\text { Monoamino mono } \\
\text { carboxylic acid (MM) }\end{array}$ & 3922.5 & 3801.5 & 4440.0 & 5429.0 & 4697.0 & 2747.5 & 3552.0 & 4105.0 & 5297.0 & 4508.0 \\
\hline $\begin{array}{l}\text { Polvamino mono } \\
\text { carboxylic acid (PM) }\end{array}$ & 495.0 & 343.5 & 295.0 & 395.0 & 291.5 & 281.0 & 392.0 & 346.0 & 321.5 & 431.5 \\
\hline $\begin{array}{l}\text { Monoamino di- } \\
\text { carboxylic acid (MD) }\end{array}$ & 1113.0 & 1400.5 & 1563.5 & 2033.5 & 1440.5 & 417.5 & 1153.0 & 1606.0 & 2073.0 & 1274.5 \\
\hline (MMin) carboxylic acid & 0.0 & 0.0 & 0.0 & 0.0 & 0.0 & 0.0 & 0.0 & 0.0 & 0.0 & 0.0 \\
\hline Sweet amino acid** & 3235.0 & 3224.0 & 3930.0 & 5067.5 & 4278.5 & 2335.5 & 3121.5 & 3551.5 & 4558.0 & 4320.0 \\
\hline Sour amino acid** & 1113.0 & 1400.5 & 1563.5 & 2033.5 & 1440.1 & 417.5 & 1153.0 & 1606.0 & 2073.0 & 1274.5 \\
\hline Bitter amino acid** & 1182.0 & 921.0 & 804.0 & 756.5 & 709.5 & 692.5 & 822.5 & 900.0 & 1060.5 & 629.5 \\
\hline Total amino acid & 5530.0 & 5545.0 & 6300.0 & 7857.5 & 6428.5 & 3445.5 & 5097.0 & 6057.0 & 7690.5 & 6224.0 \\
\hline
\end{tabular}

Figures in the parantheses represents the \% of total amino acids.

$*$ DAP- days after pollination ; ** Sweet amino acids- threonine, serine, glycine, alanine, cystine, tyrosine and lysine; Sour amino acids- aspartic and glutamic acid ; Bitter amino acids (accompanied by slight sweetness)- valine, methionine, isoleucine, leucine, phenylalanine, histidine and arginine. 
stages of maturity. Arginine, methionine, isoleucine, leucine, tyrosine, phenylalanine and histidine were also present in small quantities. High concentraion of monoamino carboxylic acid (MM) seemed to contribute for the high content of total amino acids for both the cultivars. Next to this group, monoamino dicarboxylic acid (MD) also had quite good contribution while polyamino monocarboxylic acid (PM) had very little contribution. No iminocarboxylic acid (IMI) was present in any of the melon cultivars. Mizuno et al. (1971) also observed similar accumulation pattern of amino acid content as well as the accumulation of cystine at maturity.

In respect to organoleptic contribution, amino acids are classified into three groups (Kirimura et al., 1969). Threonine, serine, proline, glycine, alanine, cystine, tyrosine and lysine are the important contributors of sweet taste. Aspartic- and glutamic acids contribute sour taste ; whereas, valine, methionine, isoleucine, leucine, phenylalanine, histidine, and arginine have a bitter taste accompanied by slight sweetness. Considering the cumulative organoleptic assessment of the two cultivars, there was indication of higher sweetness, lower sourness and bitterness for cv. Green Wave when compared to those of Natsukei 6 gou (Table 4). But after 5 days of storing there was not much difference in this respect indicating post harvest loss of variable amino acid contents. However, it was observed that the taste index for sweetness improved with the advancement of maturity. For sourness in both the cultivars, the taste index advanced with the maturity. Because of lower content of bitter amino acid in cv. Green Wave it might had superior sweetness taste compared to cv. Natsukei 6 gou which had higher content of bitter amino acid as maturity advances.

The above results indicated that accumulation of sucrose and sweet amino acid was relatively earlier in cv. Green Wave when compared to cv. Natsukei 6 gou. Fruit of cv. Green Wave seems to achieve edible sweetness at 45 days (DAP) with quite a high content of sucrose and sweet amino acid with high brix. For cv. Natsukei 6 gou fruit of similar stage had relatively lower brix and lower content of sucrose and sweet amino acid. But the content of sour and bitter amino acid was quite similar for the corresponding stage. Because of the higher percent of sweet amino acid as compared to sour and bitter amino acids and higher sucrose fruit of cv. Green Wave were more sweeter than the fruit of cv. Natsukei 6 gou at the corresponding stage of maturity. At 50 days DAP fruit of cv. Natsukei 6 gou contained higher sucrose and brix but not to the level of the fruit of cv. Green Wave at 45 DAP. Sweet amino acid also increased but was relatively low in the fruit of cv. Green Wave of that stage. Considering the above aspects it may be concluded that fruit of $\mathrm{cv}$. Green Wave and cv. Natsukei 6 gou can be suitably harvested for optimum quality at 45 and 50 DAP, respectively. However, more postharvest stages should be studied for better conclusion on postharvest keeping quality.

\section{REFERENCES}

Eguchi, H. and K. Fujieda. 1970 Chromatographic analyses of sugar accumulation in fruits of Cucumis melo L. Bull. of Hort. Res. Sta. (Min. of Agric.\& For.) Ser. D(Kurume), 6: 49-56

Kirimura, J., A. Shimozu, A. Kimizuka, T. Ninomiya and N. Katsuya. 1969 The concentration of peptides and aminoacids to the taste of foodstuffs. J. Agr. Food Chem., 17 : 689-695

Mizuno, T., K. Kato, M. Harada, Y. Miyajima and E. Suzuki. 1971 Studies on the free sugars and 
amino acids in a fruit of muskmelon. Nippon Shokuhin Kogyo Gakkaishi, $18: 319-325$

Yoshida, T., Y. Inagawa and K. Sugiyarna. 1989 Dynamics and varietal difference of sugar constituents during fruit ripening in melon. J. Japan Soc.Hort. Sa., 58(Suppl. 2) : 202-203 